\title{
Effects of Showing Forest Simulation Results on SFM Preferences of Forest Users in Central Labrador
}

\author{
Kati Berninger ${ }^{*}$, , Daniel Kneeshaw ${ }^{\mathrm{a}}$, Wiktor Adamowicz ${ }^{\mathrm{b}}$ and Christian Messier ${ }^{\mathrm{a}}$ \\ ${ }^{a}$ Centre D'Étude De La Forêt (CEF), Université du Québec à Montréal (UQAM), Canada \\ ${ }^{b}$ Department of Rural Economy, University of Alberta, Edmonton, Canada
}

\begin{abstract}
This research aims at evaluating the effectiveness of communicating simulation results to enhance learning. This was done by testing whether showing simulation results which demonstrate the long-term effects of different management strategies in a large area changes people's SFM preferences. Forest users in Central Labrador were shown simulation results of three alternative forest management scenarios illustrating possible long term effects on various indicators. SFM preferences were measured using an attribute-based choice experiment before and after the presentation. Based on earlier research and issues closely related to the attributes used in the choice experiment, we expected significant preference change and more consistent choices after presentation. No significant change was found, however. This may be due to the relative stability of SFM preferences in the region. It is also possible that more participants and a longer time frame would be needed to reveal change. However, detected changes in the parameter estimates for cut block size and alternative-specific constant (ASC), measuring the tendency of selecting the status quo alternative, indicate that some learning occurred during the process.
\end{abstract}

Keywords: Preference change, preference construction, choice experiment, forest simulation, SELES, scale, SFM.

\section{INTRODUCTION}

Sustainable forest management (SFM) involves consideration of diverse values. In order to guide decision-making on SFM, stated preference methods have been used to elicit information on assigned forest values of the public or user groups $[1,2]$. Forest management on public land typically includes decisions that have long term effects on large areas, and it is difficult to understand the possible effects of these decisions without sophisticated planning tools [3, 4]. It is highly probable that the preferences elicited in standard processes do not include insight into the long-term effects that extend to several generations on landscape-scale forest areas. Modeling tools may be used to enhance understanding of these complex issues and simulation results have been communicated to various publics as a part of public participation processes [5-8]. Communication of simulation results has a potential for enhancing learning in forest management planning processes. In order to evaluate its effectiveness in this task, we test whether showing simulation results which demonstrate the long term effect of different forest management strategies in a large area changes people's SFM preferences. Earlier work indicates that providing such information enhances learning and may change individual's forest values and attitudes towards forestry [8].

Deliberative processes which involve hearing arguments on various sides of an issue and face-to-face discussion as a means of forming informed opinions have proven useful for informing public policy [9-11]. There is a growing stream of economists applying the deliberative approach of political

*Address correspondence to this author at the Centre D'Étude De La Forêt (CEF), Université du Québec à Montréal, Canada;

E-mail: Kati_berninger@yahoo.ca sciences in economic valuation by providing the participants with relevant information and a possibility for deliberation in order to clarify their economic values for the question at hand $[2,12-14]$.

Traditional economic theory assumes that people have well established and stable preferences, but this assumption is not always met for important, complex and often unfamiliar issues like environmental or resource management questions $[15,16]$. Preferences are often constructed, not just revealed, during the elicitation process and they are shown to be context sensitive $[15,17]$. In the current research, issues related to the forest are familiar to all participants, but planning methods and forest management are unfamiliar to many. The issues of sustainable forest management are, however, complex and important to all participants. The multiattribute approach for preference construction used in this work is one way of improving valuation procedures through deliberation and information provision [18].

Mixed results exist on the effect of information or deliberation on forest management preferences. While for example Anderson [19] and Kearney [20] report a link between information and landscape preference change, Hill and Daniel [21] found no effect of information on preferences. Tyrväinen et al. [22] also reports that the landscape preferences of planning group members did not change during the planning process. These studies are all related to landscape preferences and no studies have so far been carried out on SFM preferences or on testing the effect of simulation results.

In this study, the role of additional information in stated preference experiments was examined by measuring the preferences of the same subjects before and after providing additional information in the form of forest simulation results. An earlier study with the same subjects reported some significant 
THE MULTIATTRIBUTE PROCESS APPLIED IN THIS WORK

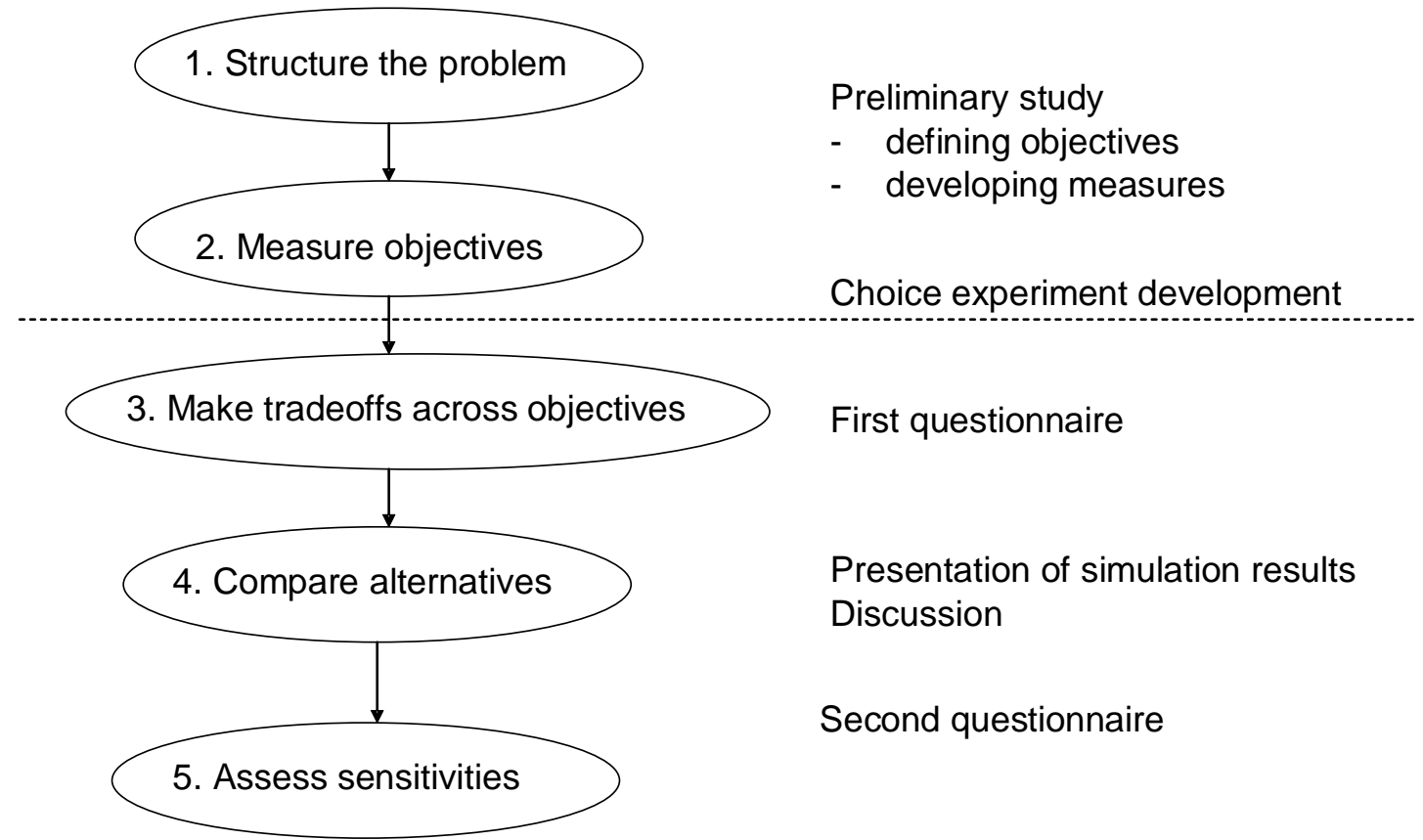

Fig. (1). Description of the multiattribute process applied in this work (modified from Gregory and Slovic [18]).

value and attitude changes after presentation of simulation results [8]. Changes in preferences are the focus of this paper, and based on the earlier results on value and attitude changes, we expected significant preference changes.

\section{METHODS}

\section{Multiattribute Approach for Preference Construction}

A multiattribute approach to preference construction has been used in order to improve valuation procedures [2, 18, 23]. The approach is based on careful elicitation of informed judgments with the depth of the participants' understanding replacing the breadth of population sampling [18].

In this work, we applied a multiattribute process (Fig. 1) inspired by Gregory and Slovic [18]. The process involved two phases of field work. The preliminary study helped to structure the problem and identified local objectives as well as potential indicators to measure sustainable forest management [24]. The choice experiment was designed to include the local objectives and measure them in a way understandable to the participants [18]. Parallel to this, development of a forest management model and simulations were carried out; this process will be further described below. A broader field study including making tradeoffs across objectives and comparison of alternatives was carried out after a careful design and testing of the choice experiment (Fig. 1). The choice experiment was repeated after a presentation of simulation results illustrating long-term effects of alternative scenarios. A sensitivity analysis is built in to the attribute based choice experiment method, since the options presented are described by a combination of various levels of the selected set of attributes.

\section{Study Area, Modeling and Simulations}

The study area was the Happy Valley - Goose Bay region surrounding the forest management District 19A in Central
Labrador which covers a land area of 2.1 million ha [8]. The forested area extends to 1.2 million ha. The biggest towns in the area are Happy Valley - Goose Bay with about 8000 inhabitants and the Innu community of Sheshatshiu with approximately 1200 inhabitants. The forest management plan for District 19A has been elaborated and is being implemented in collaboration between the government of Newfoundland and Labrador and the Innu Nation. As a result of this collaboration, the plan is based on an approach where the maintenance of cultural and ecological values is first taken care of by an extensive network of conservation areas covering approximately $50 \%$ of the territory. The remaining areas are available for logging [25].

A forest management simulation model at the landscape scale for District 19A was developed as a joint venture of various experts and local people to provide a comprehensive tool for local needs [26]. Simulations of three main forest management scenarios were run using the SELES (Spatially Explicit Landscape Event Simulator) modeling tool [27]:

1) A no conservation scenario without protected areas to represent the previous status quo (harvest level 581 $900 \mathrm{~m}^{3} /$ year).

2) A scenario that projects a continuation of the current 20 year management plan which was established in 2003 to better reflect indigenous and other local values (harvest level $222500 \mathrm{~m}^{3} /$ year).

3) An alternative plan scenario established to reduce fragmentation that includes large protected areas, but without the small habitats and special features protected in the current plan (harvest level 312300 $\mathrm{m}^{3} /$ year).

In addition to the main scenarios, variations of the current plan scenario with large (5-40 ha) and small (1-10 ha) cut blocks were tested. The time-scale of the simulations was 


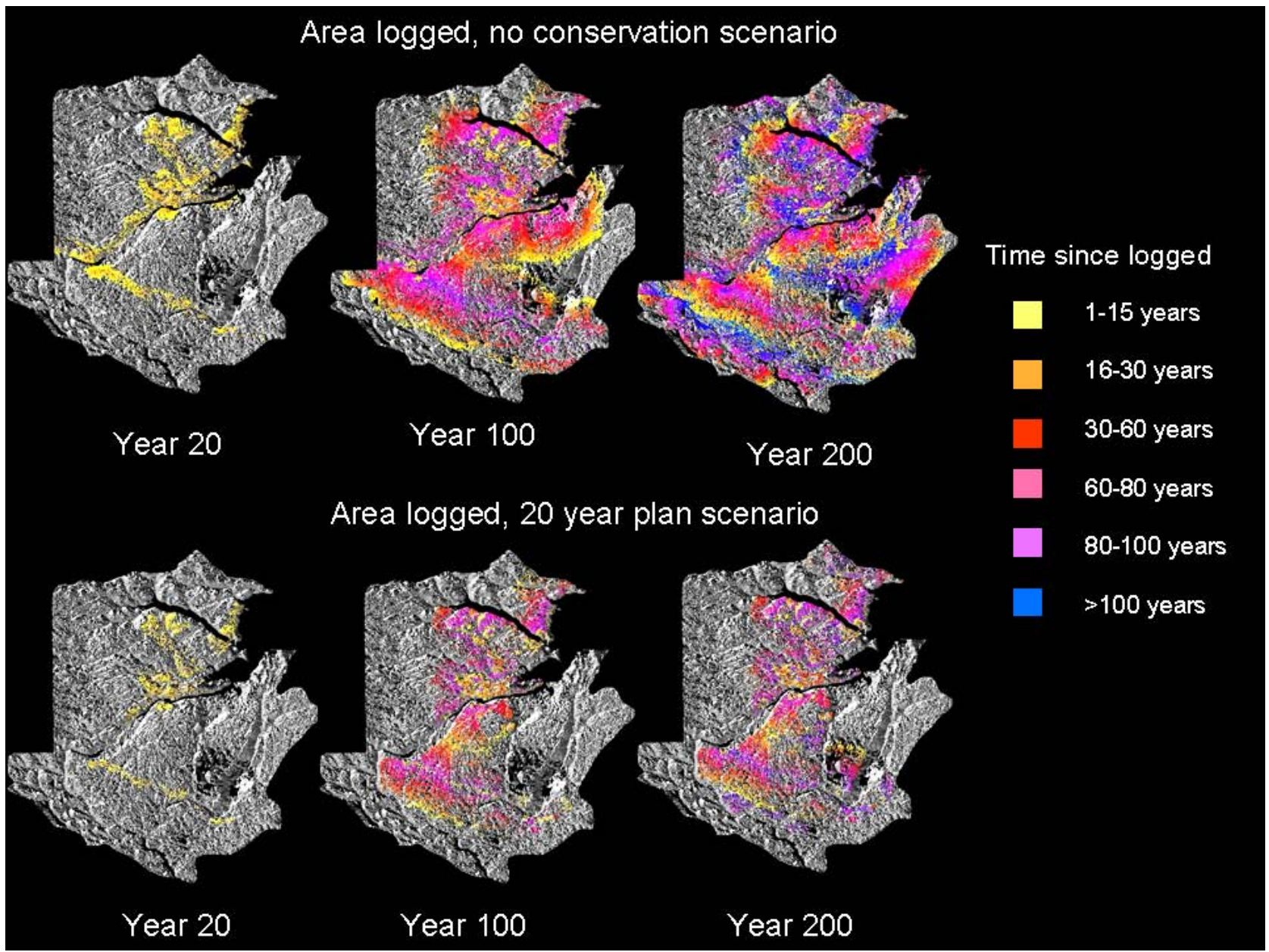

Fig. (2). An example of simulation results shown to the participants: area logged under the no conservation and the 20 year plan scenarios from year 20 to year 200 of simulation.

from 200 to 400 years. All scenarios were designed for sustainable yield which means that no reduction in the volume of wood was allowed over the long run (400 years).

Simulation results illustrating the different scenarios were shown to the participants. The long term effects of each scenario on area cut, volume of growing stock, stand age, road building and the area of old-growth forest in each forest type were presented using time series of maps, tables and graphs (an example is presented in Fig. 2). Indicators were selected to reflect the views of the local people as described in [24] taking into account limitations set by the model and the availability of data. The quantity of roads was included as an economic indicator of logging costs and an ecological indicator of habitat fragmentation. There are few existing roads in the area and new roads will have to be built in order to access new logging areas. Area of old-growth forest in each forest type is used as a coarse filter indicator of the maintenance of the ecological integrity of the forest. A significant decline in old-growth forest is interpreted as a potential risk for key species.

\section{Choice Experiments and the Survey Instrument}

We applied the choice experiment method which has been used to study trade-offs in natural resource management settings since the early 1990's [28]. In a choice ex- periment respondents are presented several choice sets which consist of different alternatives. Each alternative is described by various levels of selected attributes. The participants are asked to choose the alternative they prefer. The benefits of the method are the possibility to combine qualitative and quantitative variables and the information it provides on trade-offs among the benefits provided by the choices [29, $30]$. It can be used for studying both the use values and existence values of natural resources [31]. The design and analysis of choice experiments is based on random utility theory, where individuals are assumed to choose the alternative that maximizes their utility $[29,30]$.

According to random utility theory, the utility (U) of alternative $i$ is the sum of systematic $\left(\mathrm{V}_{i}\right)$ and error $\left(\varepsilon_{i}\right)$ components. The systematic component (V) contains specific and observable attributes that in the case of a stated preference method are defined by the researcher and presented to the individual in the form of choice sets. The presence of an error component $\varepsilon$ means that the overall utility is random and only the probability of choice of one alternative over another can be analyzed:

$\mathrm{P}(i)=\mathrm{P}\left(\mathrm{V}_{i}+\varepsilon_{i}>\mathrm{V}_{j}+\varepsilon_{j}\right) \quad \forall j \neq i, i, j \in \mathrm{C}_{n}$

where $\mathrm{C}_{n}$ is the choice set of individual $n$ [29].

In this study, five attributes were used and each attribute was assigned four levels, one of which represents the current 
situation (Table 1). We designed the attributes to represent each of the three dimensions of sustainable forest management, the ecological, the economic and the social. The attributes were based on a preliminary study conducted in 2005 where participants were asked to list and rank sustainable forest management indicators in five meetings [24]. The proportion of forested land put into conservation areas is an ecological variable, but wildlife species the forest supports combines both ecological aspects and social aspects in the form of multiple use of the forest. Hunters want favorable conditions for game species, recreational users like to see charismatic species and enthusiasts of nature observation seek rare species. The average size of clear cuts was included because many people in the preliminary study were against big clear cuts and preferred selection cutting. Forest sector jobs describe the socioeconomic role of forestry in the region and the decrease or increase in annual household expenses describes the costs of possible additional conservation areas or the gains of reducing conservation areas for the personal economy of the respondent.

The questionnaire starts by asking the participants background information and questions related to forest values and attitudes that were used to introduce the participants to the topic of SFM. The results on value and attitude change are presented in [8]. In the choice experiment section, each participant was presented eight different choice tasks, where an individual compares the current situation with two possible future scenarios. The study included all together 16 different choice tasks. Thus two different versions of the questionnaire were used and were distributed alternately to the respondents. The combinations of the levels of different attributes used in the choice tasks were determined using orthogonal tables that are developed especially for choice experiments and proven efficient [32]. The questionnaires were tested by a small group of people and adjusted accordingly. Table 2 shows an example of a choice task.

The choice experiment data was analyzed using the conditional logit model with the MDC procedure of the SAS statistical package [33] as well as the statistical package Limdep [34]. Models were estimated for preferences elicited before and after presenting the simulation results. An alternative specific constant (ASC) was estimated to measure the tendency to select options representing the current situation [30]. Both linear and squared models were estimated for each data set. Linear models were a better fit to the data than squared models. Thus all the results presented here are based on linear models. Pairwise likelihood ratio tests were conducted with SAS to test whether the parameters of the models estimated for the situations before and after presenting the simulation results differed significantly [35, p. 335-337]. Persons who always selected status quo in the first questionnaire $(n=4)$ were excluded since it was interpreted that they didn't actually make any meaningful choices. This practice has been employed elsewhere, especially in cases where

Table 1. Sustainable Forest Management Themes, Related Attributes and their Levels

\begin{tabular}{|c|c|}
\hline Theme and Attribute & Levels \\
\hline $\begin{array}{l}\text { Nature } \\
\text { Conservation area, \% forest land }\end{array}$ & $\begin{array}{l}50 \% \text { (current situation) } \\
40 \% \\
53 \% \\
56 \%\end{array}$ \\
\hline $\begin{array}{l}\text { Silviculture } \\
\text { Average size of clear cuts, ha }\end{array}$ & $\begin{array}{l}10 \text { ha (current situation) } \\
\text { selective cutting, } \\
5 \text { ha }(50 \%) \\
20 \text { ha }(200 \%)\end{array}$ \\
\hline $\begin{array}{l}\text { Multiple Use } \\
\text { Wildlife species the forest supports }\end{array}$ & $\begin{array}{l}\text { 1. The forest supports common species, } \\
\text { 2. The forest supports common species and also some spectacular large mammals } \\
\text { and birds } \\
\text { 3. The forest supports common sp., some spectacular species and some rare spe- } \\
\text { cies } \\
\text { 4. The forest supports common sp., some spectacular sp., some rare sp. and some } \\
\text { endangered species }\end{array}$ \\
\hline $\begin{array}{l}\text { Social } \\
\text { Forest sector jobs at the local and regional level }\end{array}$ & $\begin{array}{l}60 \text { (current situation) } \\
54(-10 \%) \\
66(+10 \%) \\
72(+20 \%)\end{array}$ \\
\hline $\begin{array}{l}\text { Economic } \\
\text { Increase/decrease in taxes, prices of goods and costs of services will } \\
\text { cause an increase of your annual personal expenses, change } \$ / \mathcal{E} \text { per } \\
\text { year per household }\end{array}$ & $\begin{array}{l}0 \text { (current situation) } \\
-140 \$ \\
140 \$ \\
420 \$\end{array}$ \\
\hline
\end{tabular}


Table 2. An Example of a Choice Task Presented to the Participants

\begin{tabular}{|c|c|c|c|}
\hline \multicolumn{4}{|c|}{ Please Select One of These Three Options by Checking the Box Below your Preferred Option } \\
\hline Attributes & Option 1 (Current Situation) & Option 2 & Option 3 \\
\hline $\begin{array}{c}\text { Conservation area } \% \\
\text { forest land }\end{array}$ & $50 \%$ & $\begin{array}{c}40 \% \\
\text { (Current situation-10\%) }\end{array}$ & $\begin{array}{c}53 \% \\
\text { (Current situation+3\%) }\end{array}$ \\
\hline $\begin{array}{l}\text { Average size of } \\
\text { clear cuts }\end{array}$ & 10 ha & $\begin{array}{c}5 \mathrm{ha} \\
\text { (Current situation/2) }\end{array}$ & $\begin{array}{c}20 \text { ha } \\
\text { (Current situationx2) }\end{array}$ \\
\hline $\begin{array}{l}\text { Wildlife species the } \\
\text { forest supports }\end{array}$ & $\begin{array}{l}\text { Species favored by or neutral to forestry, } \\
\text { charismatic species, some species of late } \\
\text { successional forests and some endangered sp. }\end{array}$ & $\begin{array}{l}\text { Species favored by or neutral to forestry, } \\
\text { charismatic species, some species of late } \\
\text { successional forests and some endangered sp. }\end{array}$ & $\begin{array}{l}\text { Species favored by or neutral } \\
\text { to forestry and charismatic } \\
\text { species }\end{array}$ \\
\hline Forest sector jobs & 60 & 60 & $66(+10 \%)$ \\
\hline $\begin{array}{l}\text { Increase in your } \\
\text { annual expenses, } \$ \\
\text { per household }\end{array}$ & $\$ 0$ & $\$-140$ & $\$ 140$ \\
\hline $\begin{array}{l}\text { Preferred option: } \\
\text { (Check one box) }\end{array}$ & $1 \square$ & $2 \square$ & $3 \square$ \\
\hline
\end{tabular}

some choice alternatives appear to improve upon the status quo and yet are not chosen by respondents (see [30] or [36] for a discussion of the issue and alternate strategies for dealing with this topic).

\section{Recruitment of Participants and Meetings}

The target group of this research project included residents of the Upper Lake Melville region around the town Happy Valley - Goose Bay in Central Labrador that are actively using the forest or working for its conservation. All together we organized four meetings between September $19^{\text {th }}$ and $22^{\text {nd }} 2006$ in Goose Bay. The participants were invited by email, by telephone and using a newspaper advertisement. We invited the participants to a central facility, since we wanted to present them simulation results in order to test how they affected their SFM preferences. We also wanted to give participants an opportunity to reflect thoroughly on the issue and questions at hand as well as get feedback right after presenting the simulation results.

In the meetings the participants were first familiarized with the objectives of the study, and their written consent was obtained ${ }^{1}$. The contents of the questionnaire where then explained. Each attribute was described in detail and the idea of a choice experiment was explained. The participants were then given time to fill in the first questionnaire. After that the simulation results were presented using PowerPoint slides including maps, tables and graphs of the effects of the different scenarios. After the presentation an opportunity for discussion was provided and when there were no more issues to discuss, the participants filled in the second questionnaire. The first and second questionnaires were identical with two exceptions. Background information on the participants was only collected in the first questionnaire while at the end of the second questionnaire the participants were asked to do a self evaluation of their learning and change of opinions during the meeting. The results of the self evaluation are reported in [8].

\footnotetext{
${ }^{1}$ The procedure was approved by the Research Ethics Committee of Faculty of Science at Université du Québec à Montréal (UQAM) on March $16^{\text {th }}$ 2006.
}

\section{Participants}

The study included a total of 51 participants with slightly more men than women (Table 3 ). The education level of the participants was higher than the average in Labrador, since $6.9 \%$ of the population in Central Labrador has a university degree [37].

Table 3. Demographic Characteristics of the Participants

\begin{tabular}{|l|c|}
\hline Number of Participants & 51 \\
\hline $\begin{array}{l}\text { Number of women } \\
\text { \% of all participants) }\end{array}$ & 21 \\
& $(41)$ \\
\hline Number of men & 30 \\
\hline Mean age & 51 \\
\hline Innu & 3 \\
\hline Metis & 27 \\
\hline Representing environmental groups & 9 \\
\hline Forestry professionals & 14 \\
\hline Median annual income \$ & $40000-54999$ \\
\hline Household income $\geq \mathbf{\$ 7 0 ~ 0 0 0 , ~ \% ~}$ & 25 \\
\hline University education, $\%$ & 33 \\
\hline
\end{tabular}

\section{RESULTS}

In the situation before presenting more information, all attributes except conservation had significant parameter estimates (Table 4). The positive parameter estimate indicates that alternatives with more jobs were preferred over those with fewer jobs. Also situations with more wildlife were generally preferred over situations with less wildlife. Cut block size and household costs appeared negative and significant indicating a preference for smaller cut blocks and lower costs (Table 4). The parameter estimate for conservation was not significant which indicates that it was relatively less important to the participants than the other attributes (Table 4). 
Table 4. Parameter Estimates (and Standard Errors) for Linear Models Estimated for Situations Before and After Showing Forest Simulation Results

\begin{tabular}{|c|c|c|}
\hline & Before & After \\
\hline Conservation & $\begin{array}{c}-0.004119 \\
(0.0139)\end{array}$ & $\begin{array}{c}0.006008 \\
(0.0144)\end{array}$ \\
\hline Cut block size & $\begin{array}{l}-0.0267 * \\
(0.0122)\end{array}$ & $\begin{array}{l}-0.0153 \\
(0.0125)\end{array}$ \\
\hline Wildlife $1^{\mathrm{a}}$ & $\begin{array}{c}-0.5342 * \\
(0.3077)\end{array}$ & $\begin{array}{c}0.0159 \\
(0.3171)\end{array}$ \\
\hline Wildlife $3^{\mathrm{a}}$ & $\begin{array}{l}0.5178^{*} \\
(0.2588)\end{array}$ & $\begin{array}{c}1.0652 * * * \\
(0.2717)\end{array}$ \\
\hline Wildlife $4^{\mathrm{a}}$ & $\begin{array}{c}1.2176^{* * *} \\
(0.2230)\end{array}$ & $\begin{array}{c}1.2857 * * * \\
(0.2459)\end{array}$ \\
\hline Jobs & $\begin{array}{c}0.0333 * * \\
(0.0117)\end{array}$ & $\begin{array}{l}0.0238^{*} \\
(0.0122)\end{array}$ \\
\hline Household costs ${ }^{\mathrm{b}}$ & $\begin{array}{c}-0.0772 * \\
(0.011)\end{array}$ & $\begin{array}{c}-0.1146^{* *} \\
(0.0423)\end{array}$ \\
\hline ASC & $\begin{array}{c}0.0125 \\
(0.1570)\end{array}$ & $\begin{array}{l}0.3216^{*} \\
(0.1605)\end{array}$ \\
\hline Log-likelihood & -382.74 & -371.36 \\
\hline
\end{tabular}

*** Significant at $\mathrm{p} \leq 0.001 ; * *$ Significant at $\mathrm{p} \leq 0.01$, * Significant at $\mathrm{p} \leq 0.1$.

a This variable was dummy coded., the levels of the attribute are presented in Table $\mathbf{1}$.

${ }^{\mathrm{b}}$ One unit is equivalent to 100 Canadian dollars.

$\mathrm{ASC}=$ Alternative-specific constant for the current situation

When comparing parameter estimates of the models for before and after demonstration of simulation results, there were no significant changes according to the likelihood ratio test (Likelihood ratio $=7.94, \mathrm{df}=7, \mathrm{p}=0.34$ ). The wildlife attribute maintained its statistical significance and jobs also remained important. There are, however, some changes in parameter estimates: Before presentation the parameter estimate for cut block size was negative and significant, and it became insignificant after presentation of information. Also the ASC for the current situation, which measures the tendency to choose the alternative representing the current situation, became positive and significant.

In order to further explore the data, we examined interaction effects with the attributes before and after demonstration of simulation results. We also estimated a covariance heterogeneity model and random parameter models to assess whether the impact of information arose via covariance (or scale) heterogeneity and or helped explain preference parameter heterogeneity. None of these tests revealed difference between the situation before and after presenting simulation results ${ }^{2}$. Therefore, information provided via the presentation of simulation results does not appear to affect the variance of the random utility model nor does it shift preferences in a random parameter model of preference heterogeneity.

Even if there was no statistically significant change in the choice models as described in Table 4, most participants (44,

\footnotetext{
${ }^{2}$ The statistical results are not presented here but are available from the authors upon request.
}

$86 \%$ ), changed their choices in one or more choice tasks. 27 persons $(53 \%)$ changed their choices in three or more choice tasks.

\section{DISCUSSION}

This research aimed at evaluating the effectiveness of showing simulation results that demonstrate possible longterm effects of various management alternatives on several indicators in a large area. Based on earlier research reporting some significant value and attitude change [8], we expected the presentation of simulation results to have a significant effect on the SFM preferences of the participants. We also expected the choices to become more consistent after learning more about the long-term effects of different forest management alternatives in a large area. However, we detected no significant change in preferences or in variance following the presentation of the simulation results.

Even if there was no significant difference between the models calculated for situations before and after the presentation of simulation results, the parameter estimate for cut block size changed; there was a shift away from preferring smaller cut blocks. The attribute cut block size was directly related to the simulation results presented to the participants, since it was shown that smaller cut blocks increase the need for building roads. Our result is supported by the results of [8] with the same subjects, where $12.5 \%$ of participants reported having learned and $5 \%$ having changed their opinions about the connection between the cut block size or small protected area patches and the amount of roads needed after presentation of simulation results. Previous research indicates that people may be more willing to accept larger cut blocks when they are provided with information on the benefits of avoiding forest fragmentation [38].

We also detected change in the parameter estimate for the alternative-specific constant (ASC) for the current situation towards preferring the current situation over change. A positive and significant parameter estimate for the ASC for the current situation has been interpreted as trust in the current management regime [39]. The stronger acceptance of the current situation seems to reflect the results by [8], who report that after presenting simulation results the participants showed a greater trust in the current management plan. It is assumed that the presentation illustrated the complexity of the forest management planning task in a large area concerning long time-scales and in that way increased trust on managers [8]. Alternately, it is possible that the participants realized the complexity of the issues which led them to fall back on the status quo situation, a response that is found in various other literatures on choice behavior [40].

It is possible that the additional information made the situation seem more complex and therefore increased the error variance. This effect may also have generated increased variances in some individuals and not in others and is thus a potential explanation for the lack of overall variance change in this study. It is an interesting issue worthy of further research.

There are several possible explanations for the lack of significant change in preferences after showing simulation results in this study. First, the preferences related to SFM may be relatively stable and resistant to change, as has been shown for landscape preferences [21, 22]. Second, the con- 
text of studying trade-offs between different factors of SFM may not be effective in revealing changes in one specific factor. Third, it is also possible that a larger number of participants would have revealed some significant preference change. We found some changes in the parameter estimate for cut block size and the ASC for the current situation. Also $83 \%$ of the participants changed their answers in at least one choice task. This indicates that there may have been changes that were not captured by the statistical methods used and the number of participants reached in the current study. In order to have more participants, a region with more inhabitants would be needed for further research efforts. Fourth, a significant change in preference might also need a longer time and more deliberation to occur. Finally, considering that individuals have diverse learning styles [41], the form of presentation used in this study may have been useful for some individuals and not for others.

\section{ACKNOWLEDGEMENTS}

We thank all participants and the persons who made this research possible: Neal Simon and Frank Phillips from the NL Department of Natural Resources; Valerie Courtois from the Innu Nation and Bryn Wood from the Labrador Metis Nation. We thank Andrew Fall for his work as the main modeller of the SELES model used and his support in developing indicators, building scenarios and running simulations. We thank Richard Howarth and the anonymous reviewers for valuable comments as well as Mélanie Desrochers for her help with maps. We also thank the Sustainable Forest Management Network as well as the Finnish Helsingin Sanomat Fund and the Finnish Cultural Foundation for funding.

\section{REFERENCES}

[1] Xu W, Lippke BR, Perez-Garcia J. Valuing biodiversity, aesthetics, and job losses associated with ecosystem management using stated preferences. For Sci 2003; 49: 247-57.

[2] Shapansky B, Adamowicz WL, Boxall P. Assessing information provision and respondent involvement effects on preferences. Ecol Econ 2008; 65: 626-35.

[3] Messier C, Kneeshaw D. Thinking and acting differently for sustainable management of the boreal forest. For Chron 1999; 75: 92938.

[4] Meitner MJ, Sheppard SRJ, Cavens D, et al. The multiple roles of environmental data visualization in evaluating alternative forest management strategies. Comput Electron Agric 2005; 49: 192-205.

[5] Fall A, Daust D, Morgan DG. A framework and software tool to support collaborative landscape analysis: Fitting square pegs to square holes. Trans GIS 2001; 5: 67-86.

[6] Messier C, Fortin M-J, Schmiegelow F, et al. Modelling tools to assess the sustainability of forest management scenarios. In: Burton PJ, Messier C, Smith DW, Adamowicz WL, Eds. Towards sustainable management of the boreal forest. Ottawa, NRC Research Press 2003; 531-80.

[7] Sheppard S, Meitner M. Using multi-criteria analysis and visualisation for sustainable forest management planning with stakeholder groups. For Ecol Manage 2005; 207: 171-87.

[8] Berninger K, Kneeshaw D, Messier C. Effects of presenting forest simulation results on the forest values and attitudes of forestry professionals and other forest users in Central Labrador. For Policy Econ 2009, Accepted.

[9] Fishkin K. Democracy and deliberation - New directions for democratic reform. Yale University Press, New Haven and London, 1991.

[10] Fishkin J. The voice of the people - public opinion and democracy. Yale University Press, New Haven and London, 1995.

[11] Arvai JL, Gregory R, McDaniels TL. Testing a structured decision approach: Value-focused thinking for delibereative risk communication. Risk Anal 2001; 21: 1065-76.
[12] Gregory R, Wellman K. Bringing stakeholder values into environmental policy choices: a community-based estuary case study. Ecol Econ 2001; 39: 37-52.

[13] James RF, Blamey RK. Deliberation and economic valuation: National park management. In: Getzer M, Spash C, Stagl S, Eds. Alternatives for environmental valuation. London, New York, Routledge 2005; 225-43.

[14] Howarth RB, Wilson MA. A theoretical approach to deliberative valuation: Aggregation by mutual consent. Land Econ 2006; 82: 116 .

[15] Slovic P. The construction of preference. Am Psychol 1995; 50: 364-71.

[16] Norton B, Constanza R, Bishop R. The evolution of preferences: Why 'sovereign' preferences may not lead to sustainable policies and what to do about it. Ecol Econ 1998; 24: 193-211.

[17] Schläpfer F. Contingent valuation: A new perspective. Ecol Econ 2008; 64: 729-40.

[18] Gregory R, Slovic P. A constructive approach to environmental valuation. Ecol Econ 1997; 21: 175-81.

[19] Anderson LM. Land use designations affect perception of scenic beauty in forest landscapes. For Sci 1981; 27: 392-400.

[20] Kearney AR. Effects of an informational intervention on public reactions to clear-cutting. Soc Nat Resour 2001; 14: 777-90.

[21] Hill D, Daniel T. Foundations for an ecological aesthetic: Can information alter landscape preferences? Soc Nat Resour 2008; 21: 34-49.

[22] Tyrväinen L, Silvennoinen H, Kolehmainen O. Ecological and aesthetic values in urban forest management. Urban For Urban Green 2003; 1: 135-49.

[23] McDaniels T, Roessler C. Multiattribute elicitation of wilderness preservation benefits: a constructive approach. Ecol Econ 1998; 27: 299-312.

[24] Berninger K, Kneeshaw D, Messier C. The role of cultural models in local perceptions of SFM - differences and similarities of interest groups from three boreal regions. J Environ Manage 2009; 90: 74051.

[25] Forsyth J, Innes L, Deering K, Moores L. Forest Ecosystem Strategy Plan for Forest Management District 19 Labrador/Nitassinan. Northwest River: Innu Nation and Newfoundland and Labrador Dept of Forest Resources and Agrifoods 2003.

[26] Sturtevant B, Fall A, Kneeshaw D, et al. A toolkit modeling approach for sustainable forest management planning: Achieving balance between science and local needs. Ecology and Society [serial on the internet] 2007; [cited 2008 May 20] 12(Pt 2): 7. Available from: http://www.ecologyandsociety.org/vol12/iss 2/art7/

[27] Fall A, Fall J. A domain-specific language for models of landscape dynamics. Ecol Modell 2001; 14: 1-18.

[28] Adamowicz WL, Louviere J, Williams M. Combining revealed and stated preference methods for valuing environmental amenities. J Environ Econ Manage 1994; 26: 271-92.

[29] Adamowicz WL, Swait J, Boxall PC, Louviere J, Williams M. Perceptions versus objective measures of environmental quality in combined revealed and stated preference models of environmental valuation. J Environ Econ Manage 1997; 32: 65-84.

[30] Adamowicz WL, Boxall P, Williams M, Louviere M. Stated preference approaches for measuring passive use values: Choice experiments and contingent valuation. Am J Agric Econ 1998; 80: 64-75.

[31] Grafton RQ, Adamowicz W, Dupont D, Nelson H, Hill RJ, Renzetti $S$. The economics of the environment and natural resources. Malden, Oxford, Carlton: Blackwell Publishing; 2004.

[32] Sloane NJA. A Library of Orthogonal Arrays. [homepage on the internet]. [cited 2006 April 18]. Available from: http://www.rese arch.att.com/ njas/oadir/

[33] Documentation for the 8.2 release of the MDC procedure. [monograph on the internet] SAS institute; 2001 [cited 2007 May] Available from: http://support.sas.com/rnd/app/doc.html

[34] Greene W. LIMDEP 9.0 Reference Guide. Econometric Software, Inc., Plainview 2007.

[35] Hensher DA, Rose J-M, Greene WH. Applied Choice Analysis: A primer. Cambridge: Cambridge University Press 2005.

[36] Von Haefen R, Massey DM, Adamowicz WL Serial nonparticipation in repeated discrete choice models. Am J Agric Econ 2005; 87: 1061-76.

[37] Jong C. Post-secondary education in Labrador. [monograph on the internet]. Memorial University of Newfoundland; 2007 [cited 2007 
April 16]. Available from: http://www.mun.ca/vpacademic/PSE_ Labrador_final_Jan07.doc

[38] Meitner MJ, Gandy R, D'Eor RG. Human perceptions of forest fragmentation: Implications for natural disturbance management. Forestry Chronicle 2005; 81: 256-64.

[39] Berninger K, Adamowicz WL, Kneeshaw D, Messier C. SFM preferences of interest groups in three regions varying in impor- tance of industrial forestry: An attribute-based choice experiment. J Environ Manag 2009, Accepted.

[40] Beshears J, Choi JJ, Laibson D, Madrian BC. How are preferences revealed? J Public Econ 2008; 92: 1787-94.

[41] Biggs J. Teaching for quality learning at university. Society for Research into Higher Education Buckingham: Open University Press; 2003.

Received: October 29, 2008

(C) Berninger et al.; Licensee Bentham Open

This is an open access article licensed under the terms of the Creative Commons Attribution Non-Commercial License (http://creativecommons.org/licenses/by$\mathrm{nc} / 3.0 /$ ) which permits unrestricted, non-commercial use, distribution and reproduction in any medium, provided the work is properly cited. 